\title{
DESIGN: HISTÓRIA E PROJETO
}

\author{
Marcos da Costa Braga - bragamcb@usp.br
}

FAU USP - Curso de Design da (não tem habilitação)

Disciplina optativa do $10^{\circ}$ semestre - 60 horas-aula

O Curso de Design da FAU USP tem duração de 5 anos, com entrada anual de 40 alunos e não possui habilitação. Ocorre no período noturno e possui sua grade curricular estruturada em três grandes eixos formativos (Teoria e História, Projeto e Tecnologia) segundo o seu Projeto Político Pedagógico de 2006, ano do inicio do curso.

A disciplina optativa 'Design: História e Projeto' é oferecida aos alunos do último ano do curso após terem cursado a sequência de disciplinas história do design que vai do $3^{\circ}$ ao $6^{\circ}$ semestre. Ela é interdepartamental para possibilitar ser ministrada por professores dos três departamentos da FAU USP. Foi criada em 2009 com base em experiência didática aplicada pelo mesmo docente na disciplina de 'Seminário IV' do curso de Desenho Industrial da Faculdades Integradas Silva e Souza de 1992 a 1995, no Rio de Janeiro. E foi oferecida pelo Prof. Dr. Marcos Braga em 2010 em conjunto com a Profa Dra. Clice Mazzilli e em 2011 com a Profa. Dra. Denise Dantas, ambas do Depto de projeto da FAU USP.

Essa disciplina optativa tem como foco o reestudo e análise das características dos principais movimentos, escolas, correntes de pensamento e 'fases' da história do Design Moderno, no mundo e no Brasil, que foi abordada na sequência anterior das quatro disciplinas de história do design, com vistas à revisão dos conceitos e paradigmas desse design moderno segundo o seu processo histórico, social e cultural, com o objetivo de desenvolver um projeto com as características de época. Portanto, pretende ser uma opção complementar à formação obtida pelo estudante nos anos anteriores do currículo.

Os objetivos específicos das disciplinas para com a formação do estudante são: exercitar o aluno na observação das relações entre Design e contextos sociais, culturais e ideológicos; demonstrar ao aluno as origens e antecedentes das características e paradigmas que marcam o

Braga, Marcos da Costa. "Design: História e Projeto", in Anais do 1o Seminário Paulista do ensino da história do design 2014 [= Blucher Design Proceedings, num.3, vol. 1]. São Paulo: Blucher, 2014. 
design hoje, auxiliando a apreensão da atualidade; exercitar o aluno sobre a aplicação de conceitos na configuração formal de comunicação e produtos de design; e exercitar o desenvolvimento e flexibilização do uso de linguagens estético-simbólicas e as relações com suas possíveis aplicações.

O curso é dividido em três módulos: fase informativa, fase analítica e fase aplicada.

0 primeiro é de caráter informativo e revisa e analisa os principais movimentos, correntes de pensamento e/ou fases da história do design Industrial, através de um panorama geral, enfatizando suas essências e princípios.

O segundo módulo inicia-se com a escolha conjuntamente com a turma de uma dessas fases que sirva como objeto de estudo específico, a ser pesquisado mais detalhadamente, pelos alunos.

No terceiro módulo, são desenvolvidas peças de design gráfico ou de produto que possuam os preceitos ou características peculiares do movimento, grupo, ou da obra do personagem da fase histórica estudada.

Conforme as preferências manifestadas pela turma, com vistas a suprir deficiências ou atender intenções de maiores aprofundamentos, escolhe-se e enfatiza-se algumas das fases históricas específicas dentre as consideradas importantes pelo curso. Este procedimento de certo modo facilita o desenvolvimento do segundo módulo.

A abordagem temática da disciplina é identificar e analisar as características da relação forma e função da cultura material estudada à luz das características do movimento, corrente, personagem ou estilo do campo do design em que ela insere, relacionando esses últimos ao seu contexto histórico (social, político, econômico e cultural).

A avaliação ocorre em dois momentos: 1) apresentação de seminários por parte dos alunos, que se organizam em duplas de projetos, no final da fase analítica que constitui o $2^{\text {o }}$ módulo da disciplina e 2) apresentação de um trabalho teórico/prático no final da fase aplicada, que constitui o 3o módulo.

No seminário é apresentada a pesquisa do contexto do design em que se insere o objeto de estudo e as suas características. Ao final do seminário é entregue um trabalho monográfico com a pesquisa descrita (contextos, fontes e analises) e os requisitos e fundamentos que nortearão as soluções a serem desenvolvidas no projeto. 0 trabalho deve conter uma análise da relação forma e função das peças de design pesquisadas (cores, tipografia, diagramação, elementos pictóricos, características que insere a peça no objeto de estudo e seu contexto histórico) e uma definição da abordagem para a aplicação direta ou releitura da linguagem da forma analisada. Pode ter sugestões de peças a serem projetadas ou do tema para o conteúdo a ser veiculado pelas peças. 
A abordagem para o projeto pode tomar dois caminhos: 1) direcionar-se para uma releitura que contenha elementos referenciais ao movimento estudado, ou seja, inspira-se nele, mas procura uma reinterpretação que o relacione ao presente; 2) tenta se enquadrar o projeto no "espírito" do design da época, mas com um tema contemporâneo que pode se referir a uma área da vida social, política e cultural e/ou um evento ou serviços.

No terceiro módulo, é desenvolvido um conjunto de no mínimo quatro peças de design, gráfico e de um produto de pequeno porte, conforme o tema escolhido e que possuam os preceitos e as características do design 'histórico' estudado. Porém o Cartaz é uma peça obrigatória em todos os conjuntos. Devido ao tempo disponível para o desenvolvimento de projeto, a maioria das peças desenvolvidas é de design gráfico e, em geral, se complementa o conjunto com um projeto de produto de pequeno porte e de baixa complexidade projetual. A disciplina não tem a meta de desenvolver protótipos ou maiores detalhamentos da fase de produção. Mas atinge um estágio de projeto suficiente para a aplicação dos conhecimentos específicos ministrados, incluindo propostas de materiais e meios de produção.

A apresentação final é oral, que pode ser acompanhada de projeção por computador. São entregues impressos e/ou modelos volumétricos das peças, relatório e pranchas com resumo da pesquisa, método do trabalho e descrição da solução.

As principias dificuldades apresentadas pelos estudantes durante o desenvolvimento dos trabalhos são: 1) exercitar a flexibilização do uso de linguagens estético-simbólicas e as relações com suas possíveis aplicações, provavelmente pelo condicionamento de um leque bem menor de opções de linguagens visuais permitidas ao estudante em disciplinas de projeto; 2) exercitar o uso de materiais físicos (como explorar a textura de certos papéis) e de técnicas de configuração de layouts ou de arte finais de peças de design gráfico que não são se utilizam de programas gráficos de computador, o que limita, em nossa opinião, as possibilidades criativas justamente na relação forma e função.

A História do Design tem destaque no eixo formativo 'Teoria e História' da grade curricular do Curso de Design da FAU USP. Em 2012 foi uma das sequências mais bem avaliadas desse Curso em enquete feita pelos estudantes como parte de uma avaliação geral das disciplinas do currículo. O objetivo geral da História do Design no Curso é proporcionar uma das competências previstas pelas Diretrizes Curriculares do MEC: 'visão histórica e prospectiva da área de design e a consciência das implicações econômicas, sociais, antropológicas, ambientais, estéticas e éticas da atividade do design'.

Os alunos avaliam positivamente os resultados da disciplina e demonstram consciência da complementaridade da formação da sequencia mencionada e da competência acima descrita e exercitada por eles. 